\title{
Nitrogen Fixation in Obligate Methanotrophs
}

\author{
By J. COLIN MURRELL AND HOWARD DALTON* \\ Department of Biological Sciences, University of Warwick, Coventry CV4 7AL, U.K.
}

(Received 10 May 1983)

\begin{abstract}
A number of representative species of obligate methane-oxidizing bacteria were surveyed for their ability to fix $\mathrm{N}_{2}$ by growth experiments and the acetylene reduction test. Although all strains exhibited growth on nitrogen-free plates, only type II organisms and the type $\mathrm{X}$ methanotroph Methylococcus capsulatus (Bath) grew well in nitrogen-free liquid medium and were capable of active acetylene reduction. $\mathrm{N}_{2}$-fixation in type II methanotrophs was less sensitive to $\mathrm{O}_{2}$ than in the type X methanotroph Methylococcus capsulatus (Bath) and batch cultures of type II organisms could be established at $\mathrm{pO}_{2}$ values of up to 0.2 bar. $\mathrm{N}_{2}$-fixation in Methylococcus capsulatus (Bath) was inhibited at $\mathrm{pO}_{2}$ values above 0.15 bar and the 'switch-off' of nitrogenase activity by ammonia was also observed in this organism.
\end{abstract}

\section{INTRODUCTION}

Although $\mathrm{N}_{2}$-fixing methane oxidizing bacteria have been known to exist for many years (Davis et al., 1964), initial attempts to measure $\mathrm{N}_{2}$-fixation by the classical acetylene reduction test (Dilworth, 1966; Schöllhorn \& Burris, 1967) were unsuccessful (Whittenbury et al., 1970). It was subsequently observed that acetylene was a potent inhibitor of methane oxidation (Dalton \& Whittenbury, 1976; de Bont \& Mulder, 1974) but that whole-cell nitrogenase activity could be measured if a suitable electron donor such as methanol or formate was included in this system (Dalton \& Whittenbury, 1976). Using this technique, de Bont (1976) reported that several 'Methylomonas-type' and 'Methylosinus-type' methane oxidizers (Whittenbury et al., 1970) were capable of fixing $\mathrm{N}_{2}$ although he found that the facultative organism Methylobacterium organophilum strain $\mathrm{XX}$ did not reduce acetylene.

In the few methanotrophs that have been shown to fix $\mathrm{N}_{2}$, diazotrophic growth was sensitive to $\mathrm{O}_{2}$ due to the intrinsic sensitivity of their nitrogenase proteins (de Bont \& Mulder, 1974; Dalton \& Whittenbury, 1976; Dalton, 1980). This sensitivity was manifest in the characteristic 'bell-shaped' curves for nitrogenase activity versus applied $\mathrm{pO}_{2}$ values (Dalton \& Postgate, 1969) or by the 'switch-off' phenomenon observed by Drozd \& Postgate (1970) when aerobic cultures were subjected to a sudden increase in dissolved oxygen tension (DOT).

In addition to $\mathrm{O}_{2}$, the fixed nitrogen source is also a regulator of synthesis and activity of nitrogenase in many diazotrophs. In a few organisms such as Azospirillum lipoferum (Ludden et al., 1978) and some of the Rhodospirillaceae (Zumft et al., 1981; Falk et al., 1982; Haaker et al., 1982), $\mathrm{NH}_{4}^{+}$ions inhibit $\mathrm{N}_{2}$-fixation immediately, whereas in others such as Clostridium pasteurianum (Daesch \& Mortenson, 1972) and Klebsiella pneumoniae (Gordon et al., 1981), they only affect biosynthesis of the enzyme. Several mechanisms for the short-term regulation of nitrogenase activity in vivo have been discussed (see Eady, 1981). In phototrophic bacteria it appears that the rapid inactivation of nitrogenase by ammonia is not due to changes in the membrane potential or the ATP/ADP ratio of the cell. It has been postulated that in the purple

Abbreviation: DOT, dissolved oxygen tension. 
bacteria, the response to ammonia is due to the covalent modification of the Fe protein to an inactive form (discussed by Zumft et al., 1981).

This paper reports on the distribution of the $\mathrm{N}_{2}$-fixing character of all the representative strains of obligate methanotrophs in the University of Warwick Culture Collection and investigates the effects of $\mathrm{O}_{2}$ and ammonium ions on the activity of nitrogenase in these organisms.

\section{METHODS}

Organisms. Only obligate methane-oxidizing organisms were considered in these studies and their isolation and properties have been described previously (Whittenbury et al., 1970). The type I organisms were: 'Methylomonas albus' BG8; 'Methylomonas agile' A20; Methylomonas methanica S1, A4 and PM; and 'Methylobacter capsulatus' Y. The type II organisms were: 'Methylosinus sporium' 5 and 12; 'Methylosinus trichosporium' PG, OB3b, OB5b and OB4; and 'Methylocystis parvus' OBBP. The type X strain (Whittenbury \& Dalton, 1980) was Methylococcus capsulatus (Bath).

Media. The basic mineral salts medium (MS) of Dalton \& Whittenbury (1976) was used throughout these studies. The medium was either supplemented with $1 \mathrm{~g}$ ammonium chloride $\mathrm{l}^{-1}$ to give AMS medium or $1 \mathrm{~g}$ potassium nitrate $1^{-1}$ to give NMS medium. All organisms were grown at $30^{\circ} \mathrm{C}$ with the exception of Methylococcus capsulatus (Bath) which was grown at $45^{\circ} \mathrm{C}$. Batch cultures of methanotrophs were grown in $250 \mathrm{ml}$ quickfit glass flasks fitted with Suba seals. The required $\mathrm{pO}_{2}$ for growth was established by gassing flasks with $\mathrm{N}_{2}$ after inoculation and then introducing $\mathrm{O}_{2}$ into the flask via a syringe. Continuous cultures of methanotrophs were set up as described previously (Murrell \& Dalton, 1983) with the growth-limiting substrate being $\mathrm{O}_{2}$.

Assays. Nitrogenase activity in whole cells was assayed by the method of Dalton \& Whittenbury (1976).

Culture cell dry weights were estimated by injecting washed cell suspensions into a Beckmann model 915-B total arbon analyser. The cell carbon content was assumed to be $47 \%$ of the dry weight (Van Dijken \& Harder, 1975). $3 y$ dilution of chemostat grown cells, a curve of optical density $\left(\mathrm{OD}_{540}\right)$ against dry weight was prepared for Methylococcus capsulatus (Bath). This gave average dry weight values at $\mathrm{OD}_{540} 0.1$ of $0.024 \mathrm{mg} \mathrm{ml}^{-1}$.

Measurement of methane, oxygen, nitrogen or argon in culture atmospheres was done using a Pye Unicam series 104 gas chromatograph fitted with a thermal conductivity detector and $2 \mathrm{~m} \times 4 \mathrm{~mm}$ columns filled with Molecular Sieve 5A or Porapak R.

Ammonia present in cell supernatants was measured using Nessler's reagent. Protein in cell-free extracts was measured by the Biuret method of Herbert et al. (1971).

\section{RESULTS AND DISCUSSION}

\section{The $\mathrm{N}_{2}$-fixing ability of methanotrophs}

In a preliminary experiment, single colonies of each methanotroph grown on an AMS agar plate were streaked out on to MS agar plates. Plates were incubated in a $50 \%$ methane $/ 50 \%$ air atmosphere $(\mathrm{v} / \mathrm{v})$ at $30^{\circ} \mathrm{C}$, for $5 \mathrm{~d}$ and then examined for growth. All methanotrophs exhibited some growth on these nitrogen-free plates, however, type I methanotrophs showed far less growth than the type II methanotrophs. A single colony of each organism from an AMS agar plate was inoculated into $250 \mathrm{ml}$ flasks containing $100 \mathrm{ml} \mathrm{MS}$ medium and gassed with $\mathrm{O}_{2}$ and $\mathrm{N}_{2}$ to give a range of $\mathrm{pO}_{2}$ values from 0.01 to 0.2 bar. Methane $(50 \mathrm{ml})$ was added to each flask which was then incubated for $3 \mathrm{~d}$ at the appropriate temperature on a gyratory shaker. Flasks were examined for growth by measuring the $\mathrm{OD}_{540}$ of each culture. All type 1 organisms showed little or no growth on nitrogen-free medium whereas the control flasks containing NMS or AMS medium at $\mathrm{pO}_{2}$ values of $0 \cdot 2$ bar showed good growth (Table 1). In contrast to the type I organisms, all type II methanotrophs and Methylococcus capsulatus (Bath) grew well in nitrogenfree medium. Type II methanotrophs appeared to be less sensitive to $\mathrm{O}_{2}$ than Methylococcus capsulatus (Bath) under high $\mathrm{pO}_{2}$ values suggesting that their nitrogenase proteins were either less sensitive to $\mathrm{O}_{2}$ damage than the enzyme from Methylococcus capsulatus (Bath) or that these organisms could augment respiratory activity to protect nitrogenase.

To verify that these organisms did indeed possess nitrogenase and that the observed growth was not due to scavenging of trace amounts of fixed nitrogen present in medium (see Hill \& Postgate, 1969), the acetylene reduction test was done on each culture. Cells from flasks grown at their optimum $\mathrm{pO}_{2}$ values were injected into assay flasks and re-gassed to the required $\mathrm{pO}_{2}$ values. No type I methanotrophs could reduce acetylene (results not shown) although good activities were observed with all type II cultures and Methylococcus capsulatus (Bath) (Table 2). 
Table 1. Growth of methanotrophs in nitrogen-free medium at a variety of $\mathrm{pO}_{2}$ values

Experimental details were as described in Methods. Growth was determined by measuring the $\mathrm{OD}_{540}$ after $3 \mathrm{~d}$ growth on a gyratory shaker incubator.

\begin{tabular}{|c|c|c|c|c|c|c|c|c|c|}
\hline \multirow[b]{2}{*}{ Organism } & \multicolumn{9}{|c|}{$\mathrm{OD}_{540}$ at $\mathrm{pO}_{2}$ (bar) values: } \\
\hline & 0.01 & 0.02 & 0.04 & 0.06 & 0.08 & $0 \cdot 10$ & $0 \cdot 15$ & 0.20 & Control* \\
\hline \multicolumn{10}{|l|}{ Type I } \\
\hline BG8 & 0.02 & 0.02 & 0.04 & 0.04 & 0 & 0 & 0 & 0.02 & 0.56 \\
\hline A20 & 0 & 0 & 0 & 0 & 0 & 0.03 & 0 & 0.02 & 0.31 \\
\hline S1 & 0 & 0 & 0 & 0 & 0 & $0 \cdot 04$ & 0 & 0.05 & 0.42 \\
\hline A4 & 0 & 0 & 0.04 & 0 & 0 & 0.01 & 0 & 0 & 0.27 \\
\hline PM & 0 & 0 & 0 & 0 & 0 & 0.02 & 0.02 & 0.03 & 0.44 \\
\hline $\mathrm{Y}$ & 0 & 0 & 0 & 0 & 0 & 0 & 0 & 0 & 0.62 \\
\hline \multicolumn{10}{|l|}{ Type II } \\
\hline 5 & 0 & 0.08 & $0 \cdot 21$ & $0 \cdot 27$ & 0.36 & 0.44 & 0.42 & $0 \cdot 37$ & 0.53 \\
\hline 12 & 0 & $0 \cdot 10$ & $0 \cdot 17$ & $0 \cdot 26$ & 0.36 & 0.47 & 0.45 & 0.45 & $0 \cdot 56$ \\
\hline PG & 0 & 0.12 & 0.26 & 0.32 & 0.33 & 0.47 & 0.45 & 0.45 & 0.49 \\
\hline OB3b & 0 & 0.03 & 0.14 & $0 \cdot 26$ & 0.41 & 0.49 & 0.49 & 0.51 & 0.57 \\
\hline OB5b & 0.04 & 0.09 & 0.21 & $0 \cdot 36$ & 0.41 & 0.41 & 0.41 & 0.37 & 0.48 \\
\hline OB4 & 0 & 0.08 & $0 \cdot 22$ & $0 \cdot 31$ & 0.41 & 0.42 & 0.40 & $0 \cdot 36$ & 0.48 \\
\hline OBBP & 0.02 & 0.11 & $0 \cdot 27$ & 0.29 & 0.31 & $0 \cdot 30$ & $0 \cdot 31$ & 0.28 & 0.62 \\
\hline \multicolumn{10}{|c|}{$\begin{array}{l}\text { Type X } \\
\text { Methylococcus } \\
\text { capsulatus }\end{array}$} \\
\hline (Bath) & 0 & $0 \cdot 10$ & 0.31 & $0 \cdot 40$ & 0.29 & $0 \cdot 13$ & 0.04 & 0 & 0.48 \\
\hline
\end{tabular}

Table 2. Nitrogenase activity in type II and type $X$ methanotrophs as assayed by the acetylene reduction test

The acetylene reduction test was done on cultures grown in MS medium using $150 \mathrm{mM}$-methanol as electron donor. No acetylene reduction was observed with any of the type I methanotrophs.

\begin{tabular}{|c|c|c|c|c|c|}
\hline \multirow[b]{2}{*}{ Organism } & \multirow[b]{2}{*}{$\mathrm{pO}_{2}$ (bar) ... } & \multicolumn{4}{|c|}{$\begin{array}{l}\text { Nitrogenase activity } \\
\text { [nmol ethylene produced } \min ^{-1} \\
\left.(\mathrm{mg} \text { dry wt cells })^{-1}\right]\end{array}$} \\
\hline & & 0.04 & 0.08 & $0 \cdot 12$ & $0 \cdot 20$ \\
\hline \multicolumn{6}{|l|}{ Type II } \\
\hline 5 & & $3 \cdot 5$ & $4 \cdot 1$ & $4 \cdot 2$ & $4 \cdot 0$ \\
\hline 12 & & $2 \cdot 6$ & $2 \cdot 8$ & $2 \cdot 8$ & $3 \cdot 1$ \\
\hline PG & & $2 \cdot 7$ & $3 \cdot 3$ & $3 \cdot 4$ & $3 \cdot 2$ \\
\hline OB3b & & $3 \cdot 7$ & $4 \cdot 8$ & $5 \cdot 1$ & $4 \cdot 9$ \\
\hline OB5b & & $4 \cdot 1$ & $4 \cdot 7$ & $5 \cdot 1$ & $4 \cdot 9$ \\
\hline OB4 & & 3.6 & 3.8 & 3.9 & $3 \cdot 8$ \\
\hline OBBP & & $2 \cdot 1$ & $2 \cdot 4$ & $2 \cdot 3$ & $2 \cdot 0$ \\
\hline \multicolumn{6}{|l|}{$\begin{array}{l}\text { Type X } \\
\text { Methylococc }\end{array}$} \\
\hline capsulatus (Bath) & & $2 \cdot 9$ & $3 \cdot 7$ & 0.4 & 0 \\
\hline
\end{tabular}

Of particular interest was the observation that type II methanotrophs were capable of growing on $\mathrm{N}_{2}$ and reducing acetylene at $\mathrm{pO}_{2}$ values as high as 0.2 bar because generally, chemoautotrophs only fix $N_{2}$ under microaerophilic conditions (see Dalton, 1980). To investigate this further, chemostat cultures of the type II methanotroph 'Methylosinus trichosporium' OB3b and the more oxygen-sensitive $\mathrm{N}_{2}$-fixer Methylococcus capsulatus (Bath) were established on methane. under $\mathrm{N}_{2}$-fixing conditions with $\mathrm{O}_{2}$ as the growth-limiting substrate. The oxygen tension to the cultures was then progressively increased and steady-state 


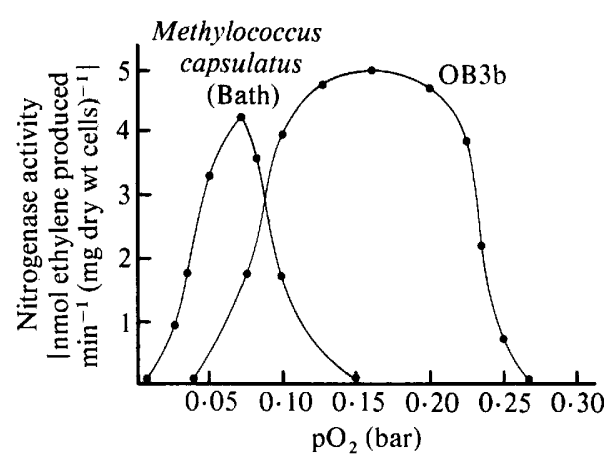

Fig. 1. $\mathrm{pO}_{2}$ profiles of nitrogenase activity in Methylococcus capsulatus (Bath) and 'Methylosinus trichosporium' $\mathrm{OB} 3 \mathrm{~b}$.

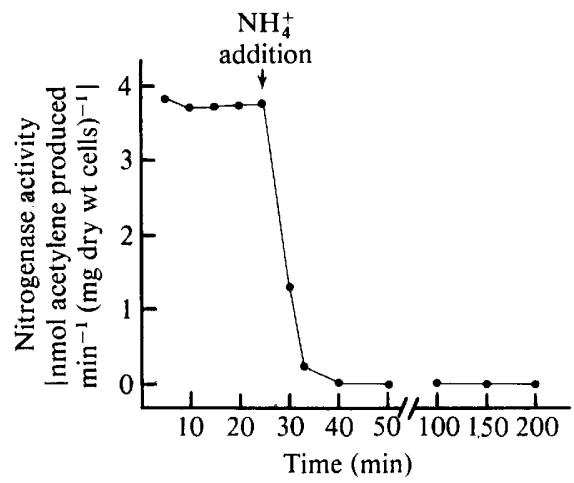

Fig. 2. Effect of 'ammonia-shock' on nitrogenase activity of a $\mathrm{N}_{2}$-fixing culture of Methylococcus capsulatus (Bath).

was established at the new DOT. The maximum DOT tolerated by Methylococcus capsulatus (Bath) was $6 \mu \mathrm{M}$ before the culture density decreased and wash-out occurred, whereas the 'Methylosinus trichosporium' OB3b culture would tolerate a DOT value of $22 \mu \mathrm{M}$ before wash-out occurred. In each case, a steady-state could be established at a DOT value of $1 \mu \mathrm{M}$ less than the wash-out value. This higher tolerance to $\mathrm{O}_{2}$ by the type II organism was also demonstrated by measuring the $\mathrm{pO}_{2}$ /acetylene reduction activity profiles of samples removed from each $\mathrm{O}_{2}$ limited chemostat in which the cell density was $0.9 \mathrm{mg}$ dry weight $\mathrm{ml}^{-1}$ and the dilution rate was $0.05 \mathrm{~h}^{-1}$ (Fig. 1). Despite the higher growth temperature of Methylococcus capsulatus (Bath), when the solubility of $\mathrm{O}_{2}$ at $45^{\circ} \mathrm{C}$ is approximately $20 \%$ lower than at $30{ }^{\circ} \mathrm{C}$, the nitrogenase from this organism exhibited a much lower $\mathrm{pO}_{2}$ optimum than the enzyme from 'Methylosinus trichosporium' OB3b.

\section{Effects of fixed nitrogen on nitrogenase activity}

No $\mathrm{N}_{2}$-fixation, as assayed by the acetylene reduction test, was observed in any AMS or NMS grown batch cultures of methanotrophs, indicating that fixed nitrogen was repressing nitrogenase. Methylococcus capsulatus (Bath) was chosen to investigate how ammonium ions exerted this effect on nitrogenase. $\mathrm{NH}_{4} \mathrm{Cl}(10 \mathrm{ml}, 1 \mathrm{M})$ was added to an $\mathrm{O}_{2}$-limited, $\mathrm{N}_{2}$-fixing culture in steady-state at a dilution rate of $0.05 \mathrm{~h}^{-1}$ to give an initial concentration of $4 \mathrm{~mm}$ $\mathrm{NH}_{4}^{+}$. After $10 \mathrm{~min}$ the nitrogenase activity of the culture had decreased to zero from $3.9 \mathrm{nmol}$ ethylene produced $\min ^{-1}\left(\mathrm{mg}\right.$ dry wt) ${ }^{-1}$ (Fig. 2), suggesting that initially $\mathrm{NH}_{4}^{+}$inhibited nitrogenase activity and not synthesis, since active nitrogenase would still be present after several hours if only synthesis was affected. The rapid 'switch-off' of nitrogenase activity by $\mathrm{NH}_{4}^{+}$is an unusual phenomenon so far only observed in a few photosynthetic $\mathrm{N}_{2}$-fixers (Zumft 
et al., 1981) and it will be interesting to learn from future studies with Methylococcus capsulatus (Bath) if a similar short-term control mechanism of nitrogenase activity operates in methanotrophs.

From these physiological studies it appears that methanotrophs may be divided into two groups on the basis of their ability to fix $\mathrm{N}_{2}$, thus strengthening the classification scheme proposed by Whittenbury \& Dalton $(1980,1982)$. Again the exception to this rule is Methylococcus capsulatus (Bath) which appears to exhibit characteristics of both groups (Whittenbury \& Dalton, 1982). Recent studies (Murrell et al., 1983), which complement data presented in this paper, have shown that specific chromosomal DNA sequences from a number of $\mathrm{N}_{2}$-fixing methanotrophs exhibit homology with the plasmid pSA30 which contains the $\mathrm{N}_{2}$ fixation structural genes $K, D$, and $H$ from Klebsiella pneumoniae (Cannon et al., 1979).

This work was supported by a SERC studentship to J.C.M.

\section{REFERENCES}

DE BoNT, J. A. M. (1976). Nitrogen fixation by methane-utilizing bacteria. Antonie van Leeuwenhoek 42, 245-253.

DE BonT, J. A. M. \& Mulder, E. G. (1974). Nitrogen fixation and co-oxidation of ethylene by a methaneutilizing bacterium. Journal of General Microbiology 83, 113-121.

Cannon, F. C., Riedel, G. E. \& Ausubel, F. M. (1979). Overlapping sequences of Klebsiella pneumoniae nif DNA cloned and characterized. Molecular and General Genetics 174, 59-66.

DAEsch, G. \& Mortenson, L. E. (1972). Effect of ammonia on the synthesis and function of the $\mathrm{N}_{2}$ fixing enzyme system in Clostridium pasteurianum. Journal of Bacteriology 110, 103-109.

Dalton, H. (1980). Chemoautotrophic nitrogen fixation. In Proceedings of the Phytochemical Society of Europe Symposium, 18. Nitrogen Fixation, pp. 177196. Edited by W. D. P. Stewart \& J. R. Gallon. London: Academic Press.

Dalton, H. \& Postgate, J. R. (1969). Effect of oxygen on growth of Azotobacter chroococcum in batch and continuous cultures. Journal of General Microbiology 54, 463-473.

DALton, H. \& WhitTEnbury, R. (1976). The acetylene reduction technique as an assay for the nitrogenase activity in the methane oxidizing bacterium Methylococcus capsulatus strain Bath. Archives of Microbiology 109, 147-151.

Davis, J. B., Coty, V. F. \& Stanley, J. P. (1964). Atmospheric nitrogen fixation by methane-oxidizing bacteria. Journal of Bacteriology 88, 468-474.

DilworTH, M. J. (1966). Acetylene reduction by nitrogen-fixing preparations from Clostridium pasteurianum. Biochimica et biophysica acta 127, 285289.

Drozd, J. \& Postgate, J. R. (1970). Effects of oxygen on acetylene reduction, cytochrome content and respiratory activity of Azotobacter chroococcum. Journal of General Microbiology 63, 63-73.

EADY, R. (1981). Regulation of nitrogenase activity. In Current Perspectives in Nitrogen Fixation, pp. 172181. Edited by A. H. Gibson \& W. E. Newton, Amsterdam: Elsevier/North-Holland Biomedical Press.

FalK, G., Johansson, B. C. \& Nordlund, S. (1982). The role of glutamine synthetase in the regulation of nitrogenase activity ('switch-off' effect) in Rhodospirillum rubrum. Archives of Microbiology 132, 251-253.

Gordon, J. K., Shah, V. K. \& Brill, W. J. (1981). Feedback inhibition of nitrogenase. Journal of Bacteriology 148, 884-888.

HaAker, H., LaAne, C., Hellingwerf, K., Hommer, B., Konings, W. N. \& Veeger, C. (1982). Shortterm regulation of the nitrogenase activity in Rhodopseudomonas sphaeroides. European Journal of Biochemistry 127, 639-645.

Herbert, D., Phipps, P. J. \& Strange, R. E. (1971). Chemical analysis of microbial cells. Methods in Microbiology 5b, 209-344.

Hill, S. \& Postgate, J. R. (1969). Failure of putative nitrogen-fixing bacteria to fix nitrogen. Journal of General Microbiology 58, 277-285.

Ludden, P. W., OKon, Y. \& BurRis, H. (1978). The nitrogenase system of Spirillum lipoferum. Biochemical Journal 173, 1001-1003.

Murrell, J. C. \& Dalton, H. (1983). Ammonia assimilation in Methylococcus capsulatus (Bath) and other obligate methanotrophs. Journal of General Microbiology 129, 1197-1206.

Murrell, J. C., Lidstrom, M. E. \& Dalton, H. (1983). Nitrogen fixation in obligate methanotrophs. In Abstracts of the Annual Meeting, American Society for Microbiology, New Orleans, 1983, p. 180. Washington, D.C.: American Society for Microbiology.

SchöllhorN, R. \& BurRIs, R. H. (1967). The reduction of azide by the $\mathrm{N}_{2}$-fixing system. Proceedings of the National Academy of Sciences of the United States of America 57, 1317-1323.

VAN DiJKen, J. P. \& Harder, W. (1975). Growth yields of microorganisms on methanol and methane. A theoretical study. Biotechnology and Bioengineering 17, 15-30.

WhitTEnBURY, R. \& DALTon, H. (1980). The methylotrophic bacteria. In The Prokaryotes, pp. 894-902. Edited by M. P. Starr, H. Stolp, H. G. Trüper, A. Balows \& H. G. Schlegel. New York: SpringerVerlag.

Whittenbury, R. \& Dalton, H. (1982). The obligate methane-oxidizing bacteria and their biotechnological potential. In Basic Biology of New Developments in Biotechnology, pp. 439-460. Edited by A. Hol- 
laender, A. I. Laskin \& P. Rogers. New York: Plenum Press.

Whittenbury, R., Phillips, K. C. \& Wilkinson, J. F. (1970). Enrichment, isolation and some properties of methane-utilizing bacteria. Journal of General Microbiology, 61, 205-218.
Zumft, W. G., Alef, K. \& MümmleR, S. (1981). Regulation of nitrogenase activity in Rhodospirillaceae. In Current Perspectives in Nitrogen Fixation, pp. 190-193. Edited by A. H. Gibson \& W. E. Newton. Amsterdam: Elsevier/North-Holland Biomedical Press. 